\title{
UJI SITOTOKSIK KOMBINASI CISPLATIN DENGAN EKSTRAK ETANOL BENALU ALPUKAT (Dendrophthoe pentandra (L) Miq.) PADA SEL HELA
}

\author{
Roihatul Mutiah ${ }^{\star 凶}$, Arief Suryadinata*, Prasasti Swara Nurani ${ }^{*}$
}

\begin{abstract}
Abstrak
Benalu alpukat (Dendrophthoe pentandra (L) Miq.) secara empiris telah digunakan sebagai obat antikanker oleh masyarakat Indonesia. Pada penelitian sebelumnya dilaporkan bahwa tanaman tersebut mengandung senyawa kuersetin. Penelitian ini bertujuan untuk mengetahui kadar kuersetin dalam ekstrak etanol $96 \%$ benalu alpukat dengan menggunakan HPLC (high performance liquid chomatography) dan untuk rnengetahui aktivitas sitotoksik kombinasi cisplatin dengan ekstrak etanol $96 \%$ benalu alpukat terhadap sel HeLa. Pengukuran kadar kuersetin dengan HPLC menggunakan kolom C-18 dan fase gerak metanol: air (59:41). Metode yang digunakan untuk uji sitotoksik adalah metode MTT assay. Hasil menunjukkan bahwa kadar kuersetin dalam ektsrak etanol $96 \%$ benalu alpukat adalah $0,116 \% \mathrm{~b} / \mathrm{v}$ atau $0,029 \mathrm{mg} / \mathrm{g}$ bahan dengan waktu retensi 6,98 menit. Ekstrak benalu alpukat menunjukkan aktivitas yang lemah terhadap sel HeLa dengan nilai $\mathrm{IC}_{50} \quad 1.000 \pm 124,68 \mathrm{ppm}$, namun tidak menutup kemungkinan digunakan sebagai agen kokemoterapi dengan cisplatin. Hasil dari kombinasi yang menghasilkan efek sinergis dalam menghambat pertumbuhan sel kanker serviks HeLa adalah kombinasi 125 ppm EBA + 2,974 nM Cis, 125 ppm EBA + 5,95 nM Cis, 125 ppm EBA + 8,925 Cis nM, 250 ppm EBA + 2,97 Cis nM, 250 ppm EBA + 5,95 nM Cis, dan 375 ppm EBA $+11,90$ Cis nM.
\end{abstract}

Kata kunci: benalu alpukat, cisplatin, kanker seviks, sel HeLa, sitotoksik.

\section{CYTOTOXIC EVALUATION OF CISPLATIN IN COMBINATION WITH ETHANOLIC EXTRACT OF AVOCADO PARASITE (Dendrophthoe pentandra (L) Miq.) AGAINST HELA CELLS}

\begin{abstract}
Avocado parasite (Dendrophthoe pentandra ( $\mathrm{L}$ ) Miq.) empirically have been used as anticancer medicine by Indonesian people. The previous studies had reported that the plant contains quercetin compound. This study aims to determine the quercetin level in $96 \%$ ethanolic extract of avocado parasite using HPLC (high performance liquid chomatography) and to examine the cytotoxic activity of the combination of cisplatin and $96 \%$ ethanolic extract of avocado parasite on HeLa cells. The measurement of quercertin level by using HPLC C-18 column and methanol moving phase: water (59:41). The methods used for cytotoxicity test is MTT assay. The result showed that the quercetin level in avocado parasite was $0.116 \%$ $\mathrm{b} / \mathrm{v}$ or $0.029 \mathrm{mg} / \mathrm{g}$ material by 6.98 minutes retention time. Avocado parasite extract shows weak activity on HeLa cell as it has IC $C_{50} 1.000 \pm 124.68 \mathrm{ppm}$. However, it is possible to be used as co-agent of chemotherapy with cisplatin. This combination results on synergistic effect in the inhibiting the growth of HeLa cells by $\mathrm{Cl}$ 0.31 (combination index) are $125 \mathrm{ppm}$ EBA + 2,974 nM Cis, 125 ppm EBA + 5,95 nM Cis, 125 ppm EBA + 8,925 Cis nM, 250 ppm EBA + 2,97 Cis nM, 250 ppm EBA + 5,95 nM Cis, dan 375 ppm EBA + 11,90 Cis nM.
\end{abstract}

Keywords: avocado parasite, cervical cancer, cisplatin, cytotoxic, HeLa cells.

*Departemen Farmasi, Fakultas Kedokteran dan IImu Kesehatan, UIN Maulana Malik Ibrahim, Malang.

$凶$ E-mail: roihatulmutiah@gmail.com 


\section{Pendahuluan}

Pada beberapa dasawarsa terakhir, angka kejadian akibat penyakit kanker mengalami peningkatan yang drastis. Data WHO tahun 2008 mencatat 12 juta kasus baru setiap tahunnya dengan jumlah angka kematian 7,6 juta jiwa. Pada data kesehatan tahun 2013 dilaporkan bahwa penyakit kanker serviks memiliki prevalensi tertinggi kedua setelah kanker payudara yaitu 0,5\% dari 220 juta penduduk Indonesia dengan jumlah angka kejadian 61.682 jiwa. ${ }^{1}$ Beberapa usaha pengobatan terhadap kanker telah dilakukan secara intensif yaitu dengan pembedahan, kemoterapi dan radioterapi, namun belum mampu secara efektif menanggulangi kanker. Kegagalan terapi tersebut disebabkan oleh target obat yang tidak spesifik dan meningkatkan multi drug resistance (MDR). Hal tersebut menimbulkan kerusakan jaringan sel normal dan menimbulkan efek samping yang serius pada pasien. ${ }^{2}$

Ko-kemoterapi merupakan salah satu solusi terhadap fenomena MDR tersebut. Ko-kemoterapi merupakan terapi yang mengkombinasikan senyawa fitokimia dari bahan alam dengan agen kemoterapi, sehingga akan meningkatkan efikasi dan menurunkan toksisitas kemoterapi terhadap jaringan normal. ${ }^{3}$ Benalu merupakan salah satu tanaman yang banyak digunakan oleh masyarakat Indonesia sebagai obat kanker secara empiris. Benalu mengandung flavonoid, tanin, asam amino, karbohidrat, dan saponin. Salah satu senyawa flavonoid yang berperan penting dalam menghambat proliferasi sel kanker dari tanaman benalu adalah kuersetin. Senyawa kuersetin dapat menghambat terbentuknya enzim DNA topoisomerase pada sel kanker. Pada penelitian sebelumnya dilaporkan bahwa ekstrak etanol benalu memiliki potensi sebagai antikanker karena pada pengujian sitotoksik dengan metode MTT (3-[4,5dimethylthiazol-2-yl]-2,5 diphenyl tetrazolium bromide) assay menghasilkan nilai $\quad \mathrm{IC}_{50}$ sebesar $<50$ $\mu \mathrm{g} / \mathrm{ml}{ }^{4}$

Pada penelitian ini akan ditentukan kandungan kuersetin pada ekstrak benalu alpukat, serta pengaruh kombinasi antara ekstrak benalu alpukat dengan cisplatin. Obat ini telah digunakan dalam pengobatan kanker kandung kemih, kepala dan leher, paruparu, ovarium, dan kanker testis. ${ }^{5}$ Kombinasi tersebut diharapkan dapat memberikan efek sinergis serta mengurangi efek samping dari cisplatin karena dosis yang digunakan adalah dosis di bawah $\mathrm{IC}_{50}$, sehingga diharapkan dengan penurunan dosis juga akan menurunkan toksisitas obat kemoterapi terhadap sel normal.

\section{Bahan dan Metode}

Benalu alpukat dikumpulkan dari Kecamatan Bantur, Kabupaten Malang. Jawa Timur, Indonesia. Determinasi tanaman dilakukan di UPT Materia Medika, Kota Batu, Jawa Timur. Fase gerak berupa etanol p.a. 99\% (Merck), aqua pro injeksi. Agen kemoterapi berupa cisplatin iv $50 \mathrm{mg} / 50 \mathrm{ml}$ (PT. Dankos Farma) yang diperoleh dari apotek Anisa Farma. Sel kanker serviks Hela diperoleh dari CCRC (Cancer Chemoprevention Research Center) UGM, sel dikultur menggunakan media MK RPMl yang mengandung 10\% FBS 
(fetal bovine serum), 1-2\% penisilin streptomisin, dan 0,5\% ampotericin $B$. DMSO untuk melarutkan ekstrak. Reagen MTT [3-(4,5-dimetiltiazol-2-il)-2, 5-difeniltetrazoliumbromida]. Reagen stopper yang digunakan adalah SDS $10 \%$ dalam $0,1 \mathrm{~N} \mathrm{HCl}$.

\section{Persiapan Sampel \\ Sebanyak $2 \mathrm{~kg}$ daun benalu alpukat segar disortasi berdasarkan kualitas lalu dikeringkan dalam oven bersuhu $50 \quad{ }^{\circ} \mathrm{C}$ selama 5 hari, selanjutnya dilakukan grinding simplisia.}

\section{Analisis kadar air \\ Analisis kadar air dilakukan dengan cara menimbang $0,5 \mathrm{~g}$ simplisia kemudian diukur kadar airnya menggunakan moisture content analyzer. Prinsip kerja alat ini yaitu dengan cara menguapkan air yang terkandung dalam sampel. Hasil penguapan air tersebut diukur sebagai persentase kadar air.}

Ekstraksi Simplisia Daun Benalu Alpukat Menggunakan Metode Ekstraksi UAE (Ultrasound Assisted Extraction)

Ekstraksi simplisia daun benalu alpukat dilakukan menggunakan metode UAE dan menggunakan pelarut etanol $96 \%$ dengan perbandingan pelarut 1:20. Perbandingan ini didapat untuk meningkatkan efektifitas dan efisiensi pelarut. $25 \mathrm{~g}$ simplisia dilarutkan dalam $500 \mathrm{ml}$ yang terbagi dalam 3 kali maserasi. Maserasi pertama yaitu $25 \mathrm{~g}$ simplisia dilarutkan dalam $200 \mathrm{ml}$ etanol $96 \%$ di UAE selama $3 \times 2$ menit lalu disaring. Filtrat ditampung dan residu diremaserasi menggunakan $150 \mathrm{ml}$ etanol $96 \%$ di UAE selama $3 \times 2$ menit lalu disaring dan filtrat ditampung, lalu diremaserasi kembali residunya dengan $150 \mathrm{ml}$ etanol $96 \%$ dan diekstraksi dengan UAE selama $3 \times 2$ menit. Lalu filtrat ditampung dan residu dibuang. Setelah filtrat ditampung, dilakukan penguapan filtrat oleh rotary evaporator.

\section{Identifikasi dan Pengukuran Kadar Senyawa Kuersetin dalam Ekstrak Etanol 96\% Daun Benalu Alpukat dengan HPLC (High Performance Liquid Chromatography)}

Pengukuran persentase kadar kuersetin dalam ekstrak benalu alpukat dengan menggunakan instrumen HPLC. Fase diam yang digunakan adalah kolom C-18 dengan fase gerak berupa metanol:air (59:41). Langkah yang pertama adalah larutan standar kuersetin dibuat dengan cara menimbang $10 \mathrm{mg}$ standar kuersetin lalu dilarutkan dalam labu ukur $10 \mathrm{ml}$ sehingga kadar kuersetin menjadi 1000 $\mu \mathrm{g} / \mathrm{ml}$. Diambil $1 \mathrm{ml}$ dan dilarutkan $10 \mathrm{ml}$ etanol ke dalam labu ukur, sehingga konsentrasinya menjadi $100 \mu \mathrm{\mu g} / \mathrm{ml}$. Dibuat larutan standar dengan cara memipet 10,30,60,120, 240, dan 480 $\mu \mathrm{L}$ dan dilarutkan sampai tanda batas $10 \mathrm{ml}$ dengan metanol ke dalam labu ukur, dan didapatkan konsentrasi larutan standar 0,$1 ; 0,3 ; 0,6 ; 1,2 ; 2,4$; dan 4,8 ppm. Disaring larutan ke dalam membran filter 0,22 $\mu \mathrm{m}$ dan diinjeksikan pada HPLC dengan sebanyak $20 \mu \mathrm{L}$. Preparasi sampel dilakukan dengan cara menimbang $25 \mathrm{mg}$ ekstrak etanol benalu alpukat (EBA) lalu dilarutkan ke dalam $10 \mathrm{ml}$ metanol dalam labu ukur, disaring dengan membran filter $0,22 \mu \mathrm{m}$ dan diinjeksikan pada HPLC dengan sebanyak $10 \mu \mathrm{L}$.

\section{Uji Sitotoksik}

Sel HeLa dikultur dalam plate 96well dalam media MK RPMI, lalu diinkubasi dalam suhu $37{ }^{\circ} \mathrm{C}$ selama 24 jam setiap well berisi $5 \times 10^{3}$ sel. Kemudian ditambahkan EBA dalam 
DMSO baik tunggal maupun kombinasi dengan konsentrasi 1000; 500; 250; $125 ; \quad 62,5 ; \quad 32,75 ; 16,375 ;$ dan 8,1875 ppm untuk dosis tunggal dan dosis MTT $0,5 \mathrm{mg} / \mathrm{ml}$ setiap well selama 3-4 jam untuk membentuk serabut formazan. Setelah 4 jam diberikan reagen SDS stop dalam $0,01 \mathrm{~N} \mathrm{HCl}$ untuk melarutkan serabut formazan dan diinkubasi kembali selama 24 jam tanpa cahaya, selanjutnya dilakukan pengukuran dengan ELISA Reader panjang gelombang $595 \mathrm{~nm}$.

\section{Analisis Kadar Air}

Data yang diperoleh berupa persentase kadar air simplisia kemudian dirata-rata dan dihitung standar deviasi.

\section{Analisis Kadar Kuersetin dengan HPLC}

Data yang diperoleh berupa waktu retensi dan kadar kuersetin dalam sampel EBA dalam bentuk ppm yang kemudian dikonversikan menjadi persentase dan $\mathrm{mg}$ kadar dalam ekstrak. Uji linearitas dilakukan pada larutan standar kuersetin $0,1: 0,3: 0,6$ : 1,2; 2,4; dan 4,8 ppm.

\section{Uji Sitotoksik}

Data yang diperoleh berupa absorbansi masing-masing sumuran dikonversikan dalam persen viabilitas sel hidup. Persen viabilitas sel hidup dihitung dengan persamaan:

$\frac{\text { absorbansi sampel }- \text { absorbansi } K M}{\text { absorbansi } K S-\text { absorbansi } K M} \times 100$ kombinasi $1 / 2 ; \quad 3 / 8 ; 1 / 4 ;$ dan $1 / 8$ lalu dilanjutkan diinkubasi selama 24 jam. Langkah selanjutnya diberikan reagen

\section{Uji Kombinasi}

Sitotoksisitas sinergistik ditetapkan dengan menghitung indeks interaksi antara agen kemoterapi EBA (ekstrak benalu alpukat) dengan $\mathrm{Cis}$ (cisplatin) dengan mengunakan persamaan:

$$
\mathrm{Cl}=(\mathrm{D})_{1} /\left(\mathrm{D}_{\mathrm{x}}\right)_{1}+(\mathrm{D})_{2} /\left(\mathrm{D}_{\mathrm{x}}\right)_{2}
$$

Pengertian $(D)_{1}$ dan $(D)_{2}$ adalah besarnya konsentrasi kedua senyawa untuk memberikan efek yang sama ( $\left.D_{\mathrm{X}}\right)$ konsentrasi tunggal senyawa untuk memberikan efek. Interpretasi indeks kombinasi $\mathrm{Cl}$ (combination index) disajikan pada Tabel 1.

Persen viabilitas yang didapatkan dari persamaan di atas selanjutnya dihitung nilai $\mathrm{IC}_{50}$ (Inhibition concentration 50\%) yaitu konsentrasi yang dapat menghambat pertumbuhan sel kanker sebesar $50 \%$ atau menyatakan potensi ketoksikan suatu senyawa terhadap sel. Semakin kecil nilai $\mathrm{IC}_{50}$ maka toksisitas semakin tinggi dan sebaliknya. ${ }^{6}$

\section{Persetujuan Etik}

Penelitian ini telah mendapatkan persetujuan etik dari Komisi Etik Penelitian Kesehatan Fakultas Kedokteran Universitas Islam Negeri Maulana Malik Ibrahim Malang dengan nomer sertifikat 005/EC/KEPKFKIK/2018.

Tabel 1. Interpretasi $\mathrm{Cl}$ (combination index)

\begin{tabular}{|c|c|c|c|c|}
\hline $\mathrm{Cl}$ & Interpretasi & $\mathrm{Cl}$ & Interpretasi & Hasil \\
\hline$<0.1$ & Strong synergist & $0.9-1.1$ & Additives & \\
\hline $0.1-0.3$ & Powerful synergist & $1.1-1.45$ & Light antagonist & Anallsı \\
\hline $0.3-0.7$ & Synergist & $1.45-3.3$ & Antagonist & $S$ \\
\hline $0.7-0.9$ & Light synergist & $>3.3$ & Powerful antagonist & Kadar \\
\hline
\end{tabular}


Kadar air dalam parameter pengukuran kualitas simplisia merupakan hal yang penting. Pengukuran kadar air ini untuk mengurangi kontaminasi mikroorganisme, yaitu sampai batas mana mikroorganisme dan kegiatan enzim dapat menyebabkan pembusukan bisa terhenti sehingga waktu simpan simplisia lebih lama. ${ }^{7}$ Pada penelitian ini menggunakan alat moisture content analyzer, alat ini berprinsip termografi dengan menguapkan air dalam serbuk hingga konstan. Penggunaan alat ini untuk menghindari senyawa antioksidan yang mudah rusak pada suhu tinggi, lebih mudah dalam operasional alat, serta harga lebih murah. Pada analisis kadar air ini, diperoleh kadar air dalam simplisia yaitu $9,07 \%$, $9,23 \%$, dan $8,70 \%$ dengan rata-rata kadar air $9 \% \pm 0,271846$. Hasil ini menunjukkan bahwa simplisia telah sesuai dengan standart Materia Medika Indonesia (1978) yaitu standar kadar air simplisia $<10 \%$.

Analisis Kadar Kuersetin dengan HPLC Kromatografi merupakan teknik pemisahan yang paling umum digunakan di bidang analisis farmasetik karena menawarkan tiga fungsi sekaligus yaitu analisis kualitatif, kuantitatif, dan preparatif. 8 Prinsip pemisahan HPLC yaitu adanya distribusi komponen-komponen dalam fase diam dan fase gerak berdasarkan perbedaan sifat fisik komponen yang akan dipisahkan. ${ }^{9}$ Uji linearitas standar kuersetin memberikan persamaan garis $y=0,470 x+0,201$ dengan koefisien relasi $\left(R^{2}\right) \quad 0,934$. Hasil kromatogram kandungan kuersetin dalam ekstrak disajikan pada Gambar 1.

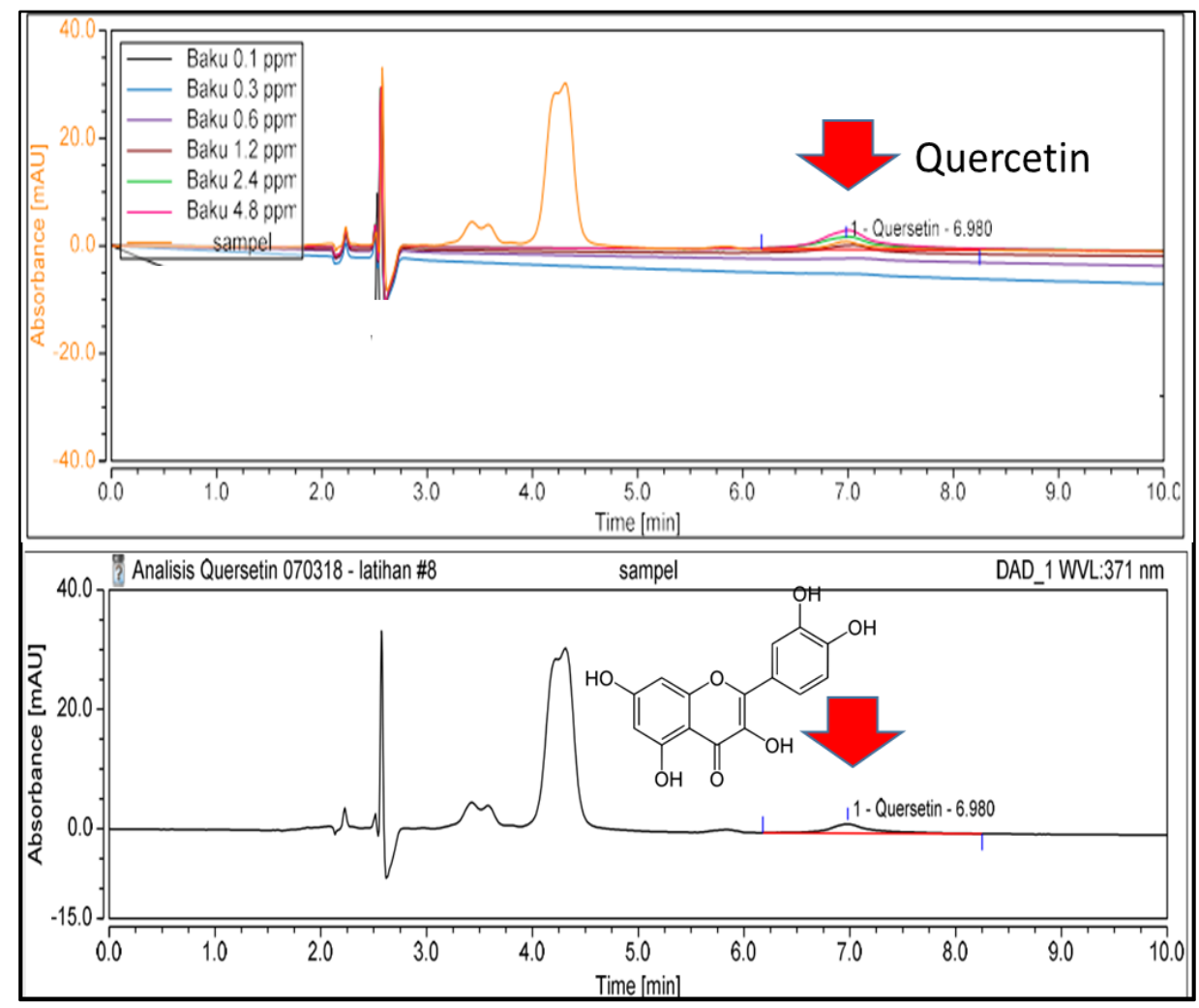

Gambar 1. Hasil kromatogram HPLC kuersetin pada ekstrak benalu alpukat (Dendropthoe petandra (L) Miq.)

\section{Uji Sitotoksik Tunggal}


Uji sitotoksik adalah langkah awal upaya pendeteksian adanya senyawa yang bekerja sebagai antineoplastik pada obatobatan yang bekerja dengan mekanisme sitotoksik. Parameter yang dihasilkan pada uji ini yaitu nilai $I \mathrm{I}_{50}$. $I \mathrm{C}_{50}$ menunjukkan nilai konsentrasi yang menghasilkan hambatan proliferasi sebesar $50 \%$ atau menyatakan potensi ketoksikan. ${ }^{6}$

Perlakuan ekstrak benalu alpukat (EBA) dan cisplatin (Cis) pada uji tunggal masing-masing senyawa terhadap sel HeLa menunjukkan pertumbuhan sel mengalami penurunan dengan adanya pertambahan konsentrasi. Nilai $\mathrm{IC}_{50}$ tunggal ekstrak benalu alpukat $1000 \pm 124,6812$ ppm. Suatu senyawa dikatakan toksik jika mempunyai nilai $\mathrm{IC}_{50}$ kurang dari $1.000 \mathrm{ppm} .{ }^{10}$ Hasil pengujian EBA dan Cis tunggal disajikan dalam Gambar 2.

Uji Kombinasi Ekstrak Benalu Alpukat (EBA) dengan Cisplatin terhadap Viabilitas dan Morfologi Sel HeLa

Konsentrasi yang digunakan pada uji kombinasi adalah 16 dosis kombinasi dengan konsentrasi di bawah $\mathrm{IC}_{50}$. Persentase sel viabel ditentukan dengan

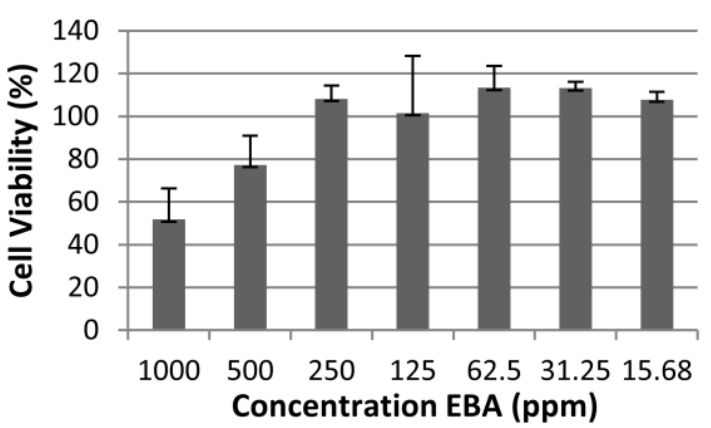

A menggunakan uji MTT. Hasil uji efektifitas bentuk kombinasi dibandingkan dengan terapi tunggalnya, sehingga bisa membandingkan efikasi sediaan kombinasi terhadap sediaan tunggalnya.

Pada perlakuan EBA dengan cisplatin baik tunggal maupun kombinasi menyebabkan perubahan morfologi pada sel HeLa yang linier dengan peningkatan konsentrasi uji. Sel HeLa pada kontrol tampak berbentuk oval dengan sitosol jernih dan melekat pada dasar tissue culture dish (TCD). Setelah perlakuan, sebagian sel tampak membulat dan terlepas dari TCD. Sel terlihat keruh dan kompak, tampak seperti mengalami kondensasi dan pengkerutan inti serta granulasi pada sitosol. Perubahan morfologi tersebut semakin nyata seiring dengan peningkatan konsentrasi uji. Perlakuan bahan uji tunggal dan kombinasi juga menurunkan viabilitas sel Hela yang linier dengan peningkatan konsentrasi uji. Penampakan morfologi sel HeLa setelah perlakuan dan setelah diberi reagen MTT untuk membentuk formazan ditunjukkan pada Gambar 3.

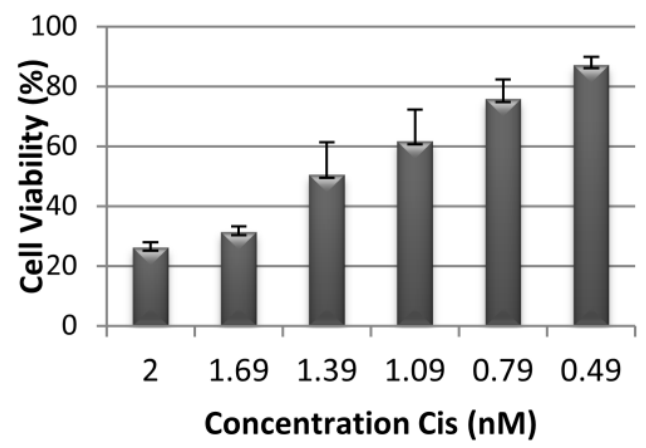

B

Gambar 2. (A). Persentase viabilitas sel HeLa setelah pemberian EBA (ekstrak benalu alpukat) dengan konsentrasi 1000-15,675 ppm. (B). Persentase viabilitas sel HeLa setelah pemberian Cisplatin dengan konsentrasi log 2-log 0,495 nM. 

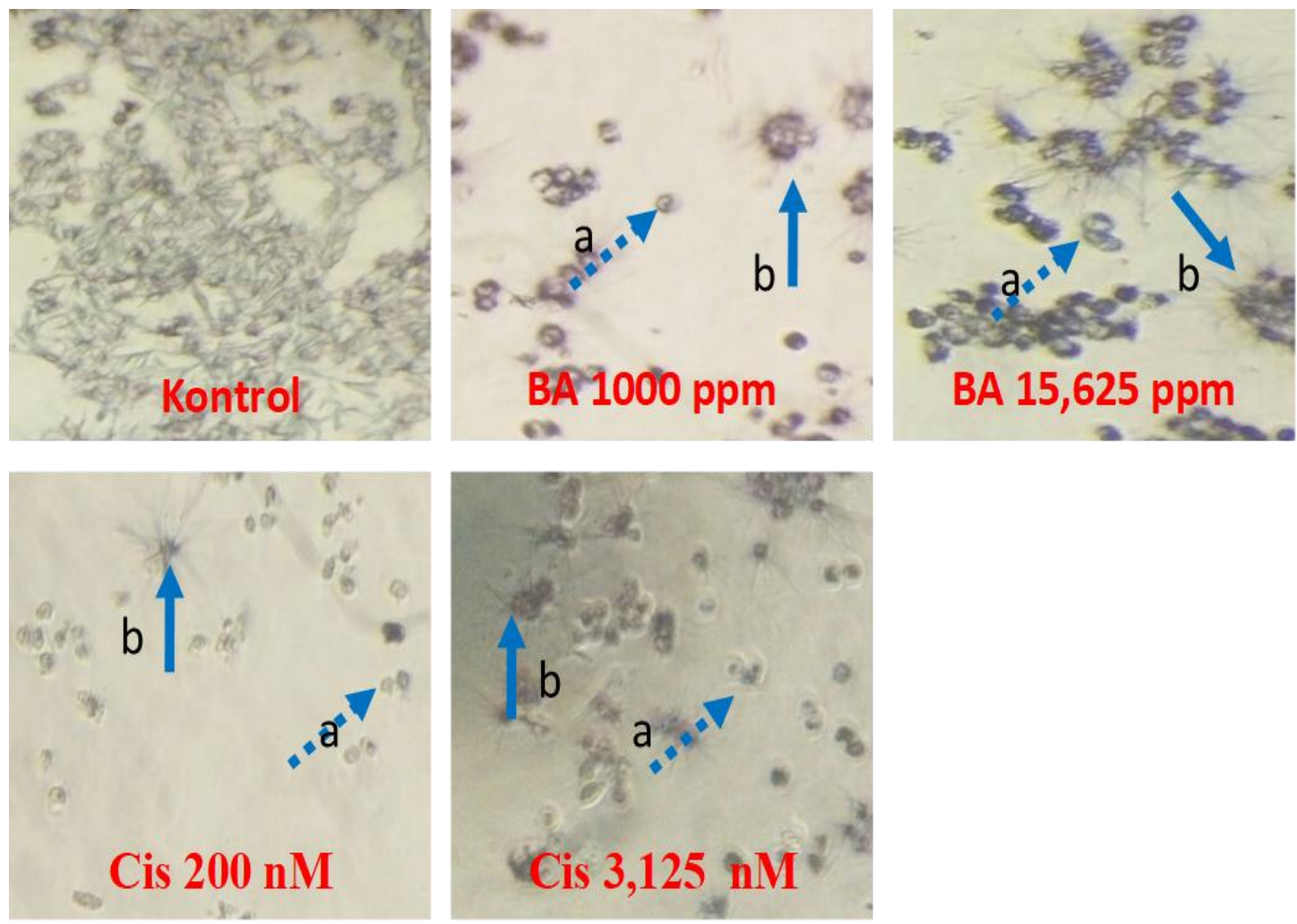

Gambar 3. Morfologi sel HeLa setelah diperlakukan dengan ekstrak benalu alpukat (EBA) dan cisplatin dengan metode uji MTT (100x). Sel mati berbentuk bulat dan membran licin (a). Sel hidup membentuk Kristal formazan dan tampak terlihat berserabut (b).

\section{Analisis Hasil Combination Index}

Metode yang digunakan untuk mengevaluasi kombinasi EBA dengan cisplatin adalah sobologram dan combination index (Cl). Analisis $\mathrm{Cl}$ kuantitatif yang menggambarkan efikasi kombinasi menggunakan persamaan $\mathrm{Cl}=(\mathrm{D}) 1 /(\mathrm{Dx}) 1+$ (D)2/(Dx)2. Cl digunakan untuk menentukan efek aditif yang diberikan dua kombinasi senyawa, apakah berupa efek sinergis, aditif atau antagonis.
Dari hasil analisis combination index EBA dengan cisplatin menunjukkan bahwa dari 16 dosis kombinasi terdapat 5 kombinasi dosis yang memberikan efek sinergis, satu sinergis ringan, 7 antagonis, 3 antagonis kuat. Hasil analisis combination index EBA dengan cisplatin ditampilkan pada Tabel 2 dan Gambar 5. 
Tabel 2. Nilai $\mathrm{Cl}$ ekstrak etanol benalu alpukat dengan cisplatin pada sel HeLa

\begin{tabular}{|c|c|c|c|c|}
\hline \multicolumn{2}{|c|}{ Doses combination } & \multirow{2}{*}{$\begin{array}{c}\text { Cell viability (\%) } \\
\text { Mean } \pm \text { SD }\end{array}$} & \multirow[t]{2}{*}{$\mathrm{Cl}$} & \multirow{2}{*}{ Therapy effects } \\
\hline EBA (ppm) & Cis (nM) & & & \\
\hline 125 & 2.97 & $93.62 \pm 5.52$ & 0.46 & Synergist \\
\hline 125 & 5.95 & $92.85 \pm 2.15$ & 0.77 & Light synergist \\
\hline 125 & 8.93 & $97.70 \pm 1.45$ & 0.70 & Synergist \\
\hline 125 & 11.90 & $89.86 \pm 5.12$ & 1.92 & Antagonist \\
\hline 250 & 2.97 & $94.63 \pm 3.21$ & 0.62 & Synergist \\
\hline 250 & 5.95 & $104.85 \pm 18.07$ & 0.47 & Synergist \\
\hline 250 & 8.93 & $88.16 \pm 1.12$ & 2.38 & Antagonist \\
\hline 250 & 11.90 & $89.66 \pm 3.49$ & 2.27 & Antagonist \\
\hline 375 & 2.97 & $84.53 \pm 2.03$ & 5.45 & Powerful antagonist \\
\hline 375 & 5.95 & $83.96 \pm 1.40$ & 72.20 & Powerful antagonist \\
\hline 375 & 8.93 & $92.36 \pm 4.73$ & 1.55 & Antagonist \\
\hline 375 & 11.90 & $84.61 \pm 2.54$ & 0.31 & Synergist \\
\hline 500 & 2.97 & $78.87 \pm 2.07$ & 49.78 & Powerful antagonist \\
\hline 500 & 5.95 & $83.03 \pm 0.73$ & 2.87 & Antagonist \\
\hline 500 & 8.93 & $71.76 \pm 15.26$ & 2.43 & Antagonist \\
\hline 500 & 11.90 & $82.22 \pm 4.64$ & 2.18 & Antagonist \\
\hline
\end{tabular}

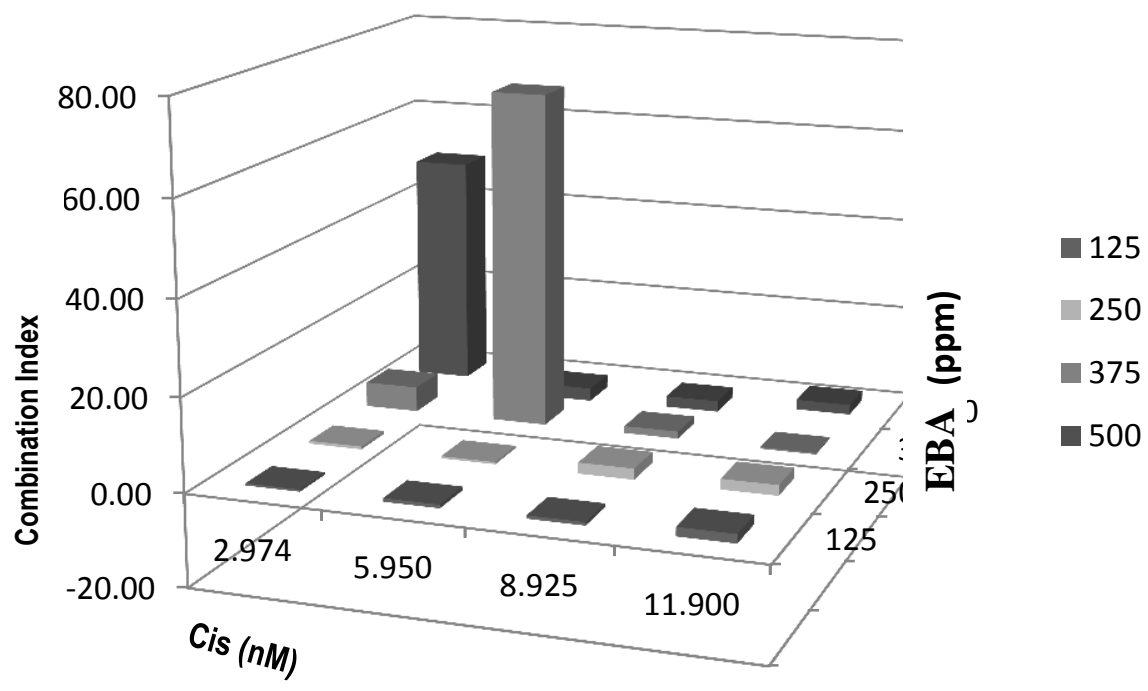

Gambar 5. Grafik indeks kombinasi cisplatin (Cis) dengan ekstrak benalu alpukat (EBA) 


\section{Pembahasan}

Sel Hela merupakan continuous cell line yang diturunkan dari epitel kanker leher rahim (cervix) seorang wanita penederita kanker leher Rahim. Kultur ini mempunyai sifat semi melekat dan digunakan sebagai model sel kanker dan untuk mempelajari sinyal tranduksi seluler. ${ }^{11}$ Sel Hela ini cukup aman dan merupakan sel manusia yang umum digunakan pada kultur sel. ${ }^{12}$ Selain mengetahui efikasi kombinasi EBA dan cisplatin penelitian ini juga bertujuan untuk menentukan kadar senyawa aktif quersetin pada ekstrak benalu alpukat dengan metode HPLC. Hal ini penting untuk dilakukan sebagai langkah awal standarisasi ekstrak untuk menjaga kestabilan efek farmakologi.

Hasil analisis pengukuran kadar kuersetin dengan metode HPLC menunjukkan bahwa larutan baku yang dibuat memiliki linieritas yang tinggi $\left(R^{2}=0,934\right)$ sehingga validitasnya juga tinggi. Berdasarkan hasil analisis didapatkan kadar kuersetin dalam EBA adalah $1,1625 \mathrm{ppm}$ atau setara dengan $0,116 \% \mathrm{~b} / \mathrm{v}$. Jika dikonversikan dalam $\mathrm{mg}$ adalah $0,029 \mathrm{mg} / \mathrm{g}$ bahan. Kadar ini sangat kecil jika dibandingkan dengan penelitian Dewata dkk (2017), yang dilakukan pada teh daun bersuhu $70{ }^{\circ} \mathrm{C}$ menggunakan instrumen spektrofotometri UV-Vis dengan kadar 2,72 $\mathrm{mg} / \mathrm{g} .{ }^{13}$ Perbedaan ini dimungkinkan karena berbagai faktor seperti ukuran simplisia, jenis pelarut, tingkat kepolaran pelarut, serta metode ekstraksi yang menentukan jenis dan jumlah senyawa yang dapat terekstrak dari bahan. ${ }^{14}$

Berdasarkan Gambar 2, diketahui nilai $I_{50}$ yang tinggi yaitu $1000 \pm 124,6812 \mathrm{ppm}$. Suatu senyawa dikatakan toksik jika mempunyai harga $\mathrm{IC}_{50}$ kurang dari 1.000 ppm. Oleh karena potensi yang didapatkan tergolong potensi lemah maka perlu dilakukan pengembangan untuk meningkatkan potensi dari tanaman benalu alpukat dengan mengembangkan menjadi fraksi atau dikembangkan melalui uji kombinasi agar potensinya meningkat. Hasil uji sitotoksisitas dari cisplatin menunjukkan nilai $\mathrm{IC}_{50}$ $23,8165965 \pm 1,46363 \mathrm{nM}$, berdasarkan data $\mathrm{NCl}$ (National Cancer Institute) tahun 2012 senyawa tersebut memiliki potensi sebagai obat antikanker terutama pada kanker serviks karena memliki I $\mathrm{C}_{50}$ kurang dari $30 \mathrm{mg} / \mathrm{\mu l} .{ }^{15}$

Kombinasi terapi (ko-kemoterapi) bertujuan untuk meningkatkan efektifitas pengobatan dan menurunkan efek samping dari agen kemoterapi. Idealnya obat yang dikombinasikan mempunyai efek yang sinergis melawan sel kanker. Namun toksisitasnya dapat ditoleransi sehingga secara klinik lebih efisien dibandingkan dengan agen tunggal. ${ }^{16}$ Perlakuan EBA dan cisplatin pada sel kanker HeLa dengan konsentrasi di bawah dosis $\mathrm{IC}_{50}$ bertujuan untuk memperoleh kombinasi dosis yang mempunyai efek antikanker yang tinggi dengan dosis yang rendah sehingga diharapkan dapat mengurangi efek samping penggunaan kemoterapi. ${ }^{14}$ Penelitian ini menunjukkan bahwa pada konsentrasi kombinasi EBA dan cisplatin yang rendah maka viabilitas sel Hela juga lebih rendah. Hal ini kemungkinan sel Hela mengalami resistensi pada konsentrasi tinggi. Pada sel yang resisten, cisplatin tidak berhasil menyebabkan kerusakan DNA sehingga p53 tidak dapat diaktifkan. Protein p53 sangat penting untuk proses pemacuan apoptosis. Sel kanker yang tumbuh sebagai parasit dianggap oleh tubuh sebagai sel sehat sehingga tubuh berkompensasi untuk melindungi sel kanker dari proses apoptosis dengan meningkatkan produksi protein Bcl-2 dan dampaknya adalah tidak terjadi apoptosis dan sel menjadi immortal. ${ }^{17}$

Beberapa kombinasi menghasilkan efek yang sinergis yaitu kombinasi 125 ppm EBA + 2,974 nM Cis, 125 ppm EBA + 5,95 nM Cis, 125 ppm EBA + 8,925 Cis nM, 250 ppm EBA + 2,97 Cis nM, 250 ppm EBA + 5,95 nM Cis, 375 ppm EBA + 11.90 Cis nM (Tabel 2 dan 
Gambar 5). Mekanisme kuersetin dalam menghasilkan efek yang sinergis diduga melalui penghambatan proses karsinogenesis yaitu dengan menghambat pembentukan enzim tirosin kinase sehingga proliferasi dapat dikendalikan. Pada obat antikanker dengan target enzim tirosin kinase memiliki efek selektif jika dibandingkan dengan mekanisme yang lain. ${ }^{4}$ Kuersetin memiliki efek yang sinergis dengan cisplatin baik secara uji in vitro maupun in vivo jika dibandingan pada pemberian cisplatin dalam terapi tunggal. ${ }^{4}$

\section{Kesimpulan}

Berdasarkan hasil analisis menggunakan HPLC kadar kuersetin dalam EBA adalah 0,029 mg/g ekstrak kental atau $0,116 \%$. Kombinasi yang menghasilkan efek sinergis adalah kombinasi 125 ppm EBA + 2,974 nM Cis, 125 ppm EBA + 5,95 nM Cis, 125 ppm EBA + 8,925 Cis nM, 250 ppm EBA + 2,97 Cis nM, 250 ppm EBA + 5,95 nM Cis, dan 375 ppm EBA $+11,90$ Cis nM.

\section{Daftar Pustaka}

1. Kemenkes RI. Data Riset Kesehatan Dasar Jakarta: Pusdatin Kemenkes RI. 2013.

2. Mardiyaningsih $A$ dan Ismiyati $\mathrm{N}$. Cytotoxic Activity of Ethanolic of Parsea americana Mill. Leaves on Hela Cervical Cancer Cell. Trad Med J. 2014; 19(1):24.

3. Nurulita NA, Meiyanto E, Sugiyanto S, Matsuda E, Kawaichi M. The Ethyl Acetate Fraction of Gynura procumbens Sensitizes WiDr Colon Cancer Cell Line Against 5Fluorouracil but Shows Antagonism with Cisplatin. International Journal of Phytomedicine. 2011; 3(3):392405.
4. Ikawati M, Wibowo $A E$, Navista $S$, dan Rosa A. Pemanfaatan Benalu sebagai Anti Kanker. Yogyakarta: Universitas Gadjah Mada. 2008.

5. Dasari $S$ and Tchounwou PB. Cisplatin in Cancer Therapy: Molecular Mechanisms of Action. Eur J Pharmacol. 2014; 0:364-378. doi: 10.1016/j.ejphar.2014.07.025.

6. Mayer BN, Ferrigini NR, Putman JE, Jacobsen LB, Nichols DE, Mclaughin JL. Brine Srimp: A Cowenient General Bioassay for Active Plant Constituelns. Planta Medica. 1982; 45:31-34.

7. Riansyah A, Supriadi A, dan Nopianti R. Pengaruh Perbedaan Suhu dan Waktu Pengeringan terhadap Karakteristik Ikan Asin Sepat Salam (Trichogasterpecotoralis) dengan Menggunakan Oven. Fishtech. 2013; 2(1): 53-54.

8. Muti'ah R. Pengembangan Fitofarmaka Antikanker Panduan Teknik Pengembangan Obat Herbal Indonesia Menjadi Fitofarmaka. Malang: UIN Maliki Press. 2014.

9. Ardianingsih R. Penggunaan High Perfomance Liquid Chromatograpy (HPLC) dalam Proses Deteksi lon. LAPAN. 2009; 10(4):102-104.

10. Haryoto $M$, Indrayudha $P$, Azizah $T$, dan Suhendi A. Aktivitas Sitotoksik Ekstrak Etanol Tumbuhan Sala (Cynometraramiflora L) terhadap Sel Hela, T47D, dan WiDR. Surakarta: Universitas Muhammadiyah Surakarta. 2013; 18(2):23.

11. Wikipedia. Hela is Also The German Name for Hel, Poland and The Cruiser SMS Hela, Wikipedia the Free Encyclopedia, Wikimedia Foundation. 2006. (Online). 
12. http://en.wikipedia.org/wiki/HeLa. Diakses 20 Januari 2018.

13. Labwork Study Guideand Lecture Notes. Henrietta Lacks. 2000. (Online). www.micro.msb.le.ac.uk/Labwork/Lack 1.html, Diakses tanggal?

14. Dewata I, Sandhi P, dan Widarta, I. Pengaruh Suhu dan Lama Penyeduhan Terhadap Aktivitas Sensoris TehHerbal Daun Alpukat (Parsea americana Mill.). Jurnal ITEPA. 2017; 6(2):30-39.

15. Hidayati F, YS Darmanto, dan Romadhon. Pengaruh Perbedaan Konsentrasi Ekstrak Sargasum sp. dan Lama Penyimpanan terhadap Oksidasi Lemak pada Fillet Ikan
Patin (Pangasius sp.). Jurnal $\| m u$ Lingkungan. 2017. 15: 66.

16. NCl. Cancer Treatment. 2012. (Online). http://www.cancer.gov/cancertopics/trea t ment. Html. Diakses 11 Februari 2018.

17. Mutiah $R$, Listiyana $A$, dan Suryadinata A. Aktivitas Antikanker Kombinasi Ekstrak Benalu Belimbing (Macrosolen cochinensis) dan Bawang Sabrang (Eleutherine palmifolia (L) Merr.) pada Sel Kanker Serviks (Sel HeLa). Trad Med J. 2017. 22(3):151.

18. Pemaron, I. Peran Protein Bcl-2 pada Resistensi Kemoterapi Golongan Cisplatin pada Kanker Ovarium. UNU.2012. 